${ }^{8}$ Copley DP, Mantle JA, Rogers WJ, Russell RO Jr, Rackely CE. Improved outcome for prehospital cardiopulmonary collapse with resuscitation by bystanders. Circulation $1977 ; \mathbf{5 6}: 901-5$.

${ }^{9}$ Armstrong A, Duncan B, Oliver MF, et al. Natural history of acute coronary heart attack. A community study. Br Heart $\mathcal{f} 1972$;34:67-80

${ }^{10}$ Bainton CR, Peterson DR. Deaths from coronary heart disease in persons fifty years of age and younger. A community-wide study. $N \mathrm{Englf}$ Med $1963 ; 268: 569-75$.

${ }^{11}$ Kinlen LJ. Incidence and presentation of myocardial infarction in an English community. Br Heart $\mathcal{f} 1973 ; 35: 616-22$.

12 McNeilly RH, Pemberton J. Duration of last attack in 998 fatal cases of coronary artery disease and its relation to possible cardiac resuscitation. Br Med f 1968;iii:139-42.

${ }^{13}$ Smyllie HC, Taylor MP, Cuninghame-Green RA. Acute myocardial infarction in Doncaster. II-Delays in admission and survival. $\mathrm{Br}$ Med $\mathcal{F}$ $1972 ; \mathrm{i}: 34-6$.

14 Colling A, Dellipiani AW, Donaldson RJ, MacCormack P. Teesside coronary survey: an epidemiological study of acute attacks of myocardial infarction. Br Med F 1976;ii:1169-72.

${ }^{15}$ Hill JD, Hampton JR, Mitchell JRA. A randomised trial of home-versushospital management for patients with suspected myocardial infarction. Lancet $1978 ; \mathrm{i}: 837-41$.

16 Theorell T, Erhardt LR, Lind E, Sjögren A, Säwe U. Selected psychosocial variables in the delay of reaching the coronary care unit. Acta Med Scand 1975;198:315-7.

17 Moss AJ, Wynar B, Goldstein S. Delay in hospitalization during the acute coronary period. Am $\mathcal{F}$ Cardiol 1969;24:659-65.
18 Tjoe SL, Luran MH. Delays in reaching the cardiac care unit. An analysis. Chest $1972 ; 61: 617-21$.

19 Hackett TP, Cassem NH. Factors contributing to delay in responding to the signs and symptoms of acute myocardial infarction. Am $\mathcal{f}$ Cardiol $1969 ; 24: 651-8$.

${ }^{20}$ Erhardt LR, Sjögren A, Säwe U, Theorell T. Prehospital phase of patients admitted to a coronary care unit. Acta Med Scand 1974;196:41-6.

21 Tunstall Pedoe H, Clayton D, Morris JN, Brigden W, McDonald L. Coronary heart attacks in East London. Lancet 1975; ii :833-8.

22 Schroeder VS, Lamb IH, Hu M. The prehospital course of patients with chest pain. Analysis of the prodromal, symptomatic, decision-making, transportation and emergency room periods. Am 7 Med 1978;64:742-8.

${ }^{23}$ Simon AB, Feinleib M, Thompson HK Jr. Components of delay in the pre-hospital phase of acute myocardial infarction. Am $\mathcal{F}$ Cardiol 1972; $30: 476-82$.

24 Gudmundsson S, Hardarson T. The determination of the duration of admission delay in acute myocardial infarction. Dan Med Bull 1978; $27: 51-5$.

${ }^{25}$ Farquhar JW, Maccoby N, Wood PD, et al. Community education for cardiovascular health. Lancet $1977 ; \mathrm{i}: 1192-5$

${ }^{26}$ Salonen JT, Puska P, Musta 'iemi H. Changes in morbidity and mortality during comprehensive comımunity programme to control cardiovascular diseases during 1972-7 in North Karelia. Br Med F 1979;ii:1178-83.

${ }^{27}$ McNeill GP, Bouchier IAD, Watson H. Mobile coronary care available to the general public. Lancet 1979;i:975.

(Accepted 5 April 1982)

\title{
Selective infection of lower respiratory tract by respiratory viruses in children with recurrent respiratory tract infections
}

\author{
D ISAACS，J R CLARKE，D A J TYRRELL， H B VALMAN
}

\begin{abstract}
Thirty preschool children presenting with recurrent respiratory infections and their unaffected siblings were observed prospectively for a year. The index children experienced more episodes of acute respiratory infection than their siblings. Respiratory viruses were the major cause of respiratory infections. The index children had lower respiratory tract disease, predominantly wheeze, during $34 \%$ of proved respiratory virus infections compared with $11 \%$ of such infections experienced by the control children $(p<0.02)$. Atopic children had an increased tendency to wheeze that did not reach significance, but atopy was not associated with increased susceptibility to respiratory infections.
\end{abstract}

\section{Introduction}

There is a large group of children with recurrent respiratory tract infections who are seen by their general practitioners and by paediatricians and for whom conventional immunological tests show no cause for their increased susceptibility to infections. ${ }^{1}$ It is not known whether such children are experiencing mainly viral or bacterial infections. The association between wheezy bronchitis and respiratory virus infections is, however,

Northwick Park Hospital and Clinical Research Centre, Harrow, Middlesex HA1 3UJ

D ISAACS, MRCP, MRC research fellow (present address: Royal Alexandra Hospital for Children, Camperdown, NSW 2050, Australia)

J R CLARKE, BSC, laboratory technician

D A J TYRRELL, FRCP, deputy director, Clinical Research Centre

H B VALMAN, FRCP, consultant paediatrician well documented. Horn and colleagues isolated respiratory viruses from tissue culture in $146(24 \%)$ of 554 episodes of acute wheezy bronchitis in children aged 0 to 12 years, and half of the viruses isolated were rhinoviruses. ${ }^{2}$ The same workers isolated rhinoviruses in large numbers from the sputum of children with wheezy bronchitis, suggesting lower respiratory tract multiplication of the virus. ${ }^{3}$

Some, but not all, children who wheeze during virus infections are atopic. ${ }^{2}{ }^{4}$ Atopy and increased bronchial lability are thought to be determined independently, since children with a persistent increase in bronchial lability after bronchiolitis are not atopic. ${ }^{5}$ It is not known whether atopy is associated with an increased susceptibility to respiratory infections; Minor et al suggested that asthmatic children are more susceptible to respiratory virus infections than their non-asthmatic siblings, ${ }^{6}$ but the total number of respiratory infections experienced by asthmatic and non-asthmatic children in their study was identical and atopic status was not specified.

We undertook a prospective study of 30 preschool children with recurrent respiratory infections and their unaffected siblings.

\section{Patients and methods}

Thirty children aged 6 months to 6 years presenting consecutively to the paediatric department with recurrent upper or lower respiratory tract infections (or both) were admitted to a prospective study. The index children were reported by their parents to have had at least 10 infections in the previous year and all had an unaffected sibling in the same age range who acted as control. Sibling pairs were observed prospectively for a year from admission to the study. The sibling control group was 1.4 years older on average than the index group ( $p<0.05$ by the Student's paired $t$ test). The mean age of the index group at presentation was $2 \cdot 2$ years. Only one index child and one control sibling were under one year of age at presentation. 
Index and control children were visited at home by one of us (DI) during each respiratory episode, a clinical diagnosis was made according to the criteria of Court ${ }^{7}$ and recorded, and specimens of respiratory secretions were obtained for viral and bacterial cultures. Nose and throat swabs were taken with sterile serum-coated wool swabs and broken into viral transport medium containing penicillin, streptomycin, and amphotericin for viral culture and plated on to blood and chocolate agar plates for bacterial culture. A neonatal mucus extractor and mucus trap (Chilton Surgical ME/30) was used to take a nasopharyngeal aspirate, to which $2 \mathrm{ml}$ of viral transport medium was added. Specimens for virus isolation were transported to the laboratory frozen on solid carbon dioxide and stored at $-70^{\circ} \mathrm{C}$ until cell cultures were available. Specimens were put up in roller-tube cultures on monolayers of MRC-5 fibroblasts, Ohio HeLa cells, LLC-MK2 monkey kidney cells, and fetal tonsil cells. ${ }^{8}$ Viruses were serotyped by virus neutralisation tests where possible. ${ }^{9} \mathrm{R}$ hinoviruses were identified by acid lability test-namely, a 100-fold reduction in titre after treatment at pH 4 for two hours. ${ }^{9}$

Venous blood was taken from index and control children at presentation, and total serum IgE concentration was measured by a double antibody inhibition radioimmunoassay technique. ${ }^{10}$ Children underwent prick tests at presentation with eight common inhalant allergen extracts: Dermatophagoides pteronyssinus, house dust, cat fur, dog fur, grass pollen, tree pollen, mixed feathers, mixed moulds, and a control solution (Bencard). Skin tests were read at 15 minutes and were positive if a weal was present with a diameter $2 \mathrm{~mm}$ or more greater than that of any control weal. ${ }^{11} 12$ Children with one or more positive skin reactions were defined as atopic. ${ }^{11} 12$

The study was undertaken with the prior approval of the Northwick Park Hospital ethical committee.

\section{Results}

The 30 index children each experienced from three to 16 clinical episodes of acute respiratory infection in a year with a mean of $9 \cdot 3 \pm$ SD 3.3 episodes/child/year, while the control siblings experienced from one to 11 episodes, mean $5 \cdot 4 \pm 2 \cdot 7$ episodes/child/year. Even after adjustment for age, which was related to the incidence of infections, the difference in the means was highly significant when analysed by paired $t$ test $(\mathrm{p}<0.001)$.

The index children had lower respiratory tract infection in 92 $(33 \%)$ of their 279 episodes compared with $16(10 \%)$ of 162 episodes

TABLE I-Viruses isolated from specimens from nasopharynx during acute respiratory infections

\begin{tabular}{lcc}
\hline & $\begin{array}{c}\text { Index } \\
(\mathrm{n}=250)\end{array}$ & $\begin{array}{c}\text { Control } \\
(\mathrm{n}=127)\end{array}$ \\
\hline Viruses: & & \\
$\quad$ Rhinovirus & 59 & 24 \\
Echovirus & 12 & 7 \\
Adenovirus & 10 & 6 \\
Respiratory syncytial virus & 7 & 3 \\
Coxsackievirus & 6 & 3 \\
Varicella & 3 & 2 \\
Mumps & 1 & 1 \\
Rubella & 1 & \\
\hline Total & 99 & 46
\end{tabular}

experienced by the control siblings (see fig 1). This difference was highly significant $(p<0.01)$ when the results were compared by weighted two-way analysis of variance of the logits of the proportions (this analysis is equivalent to a paired $t$ test but allows for a variable number of episodes experienced by each child). The index children had upper respiratory tract infection in $180(64 \%)$ of the 279 episodes compared with $143(88 \%$ ) of the 162 episodes experienced by control siblings. Middle respiratory tract infections accounted for seven $(2 \%)$ episodes in index children and three $(2 \%)$ in controls. These differences were not significant.

\section{VIRUS ISOLATION AND ILLNESS}

Viruses were isolated from tissue culture in $38 \%$ of acute infectious episodes, the virus isolation rates from index and control groups being $40 \%$ and $36 \%$ respectively (see table I). Rhinoviruses accounted for over half of all viruses isolated from each group. We did not attempt to isolate coronaviruses, and we did not succeed in isolating any influenza or parainfluenza viruses. There was no difference in the proportions of different viruses isolated from index and control groups.

The incidence of lower respiratory tract infection during proved virus infections was virtually identical to that during all episodes. The index children had lower respiratory tract infection during $34 \%$ of proved virus infections, compared with $11 \%$ of infections experienced

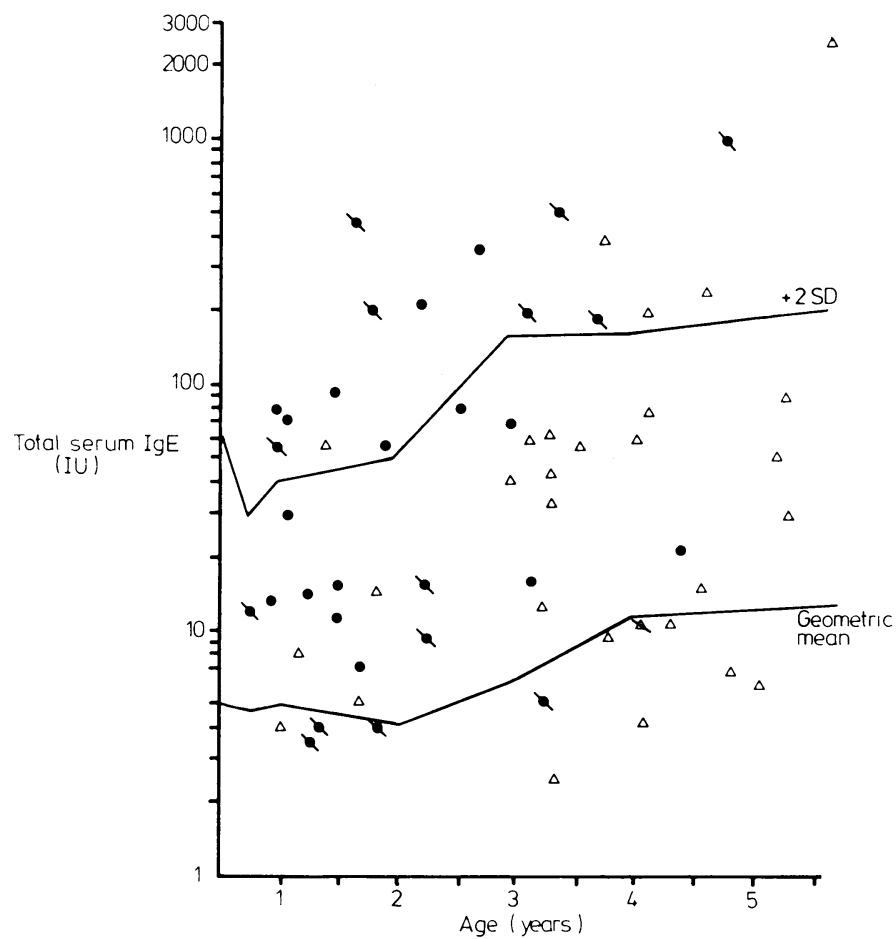

Total serum IgE concentration of study children related to normal range of Kjellman et al. ${ }^{6}=$ Index children; $\triangle=$ control children; $Q$ or $\Delta=$ four or more episodes of wheeze/year.

TABLE II-Clinical diagnosis in association with positive virus isolations

\begin{tabular}{|c|c|c|c|c|c|c|c|}
\hline & \multicolumn{4}{|c|}{ Upper respiratory tract } & \multicolumn{2}{|c|}{ Middle respiratory tract } & \multirow{2}{*}{$\frac{\begin{array}{c}\text { Lower respiratory } \\
\text { tract }\end{array}}{\text { Pneumonia }}$} \\
\hline & Common cold & $\begin{array}{l}\text { Upper respiratory } \\
\text { tract infection }\end{array}$ & Tonsillitis & Otitis media & Croup & Wheezy bronchitis & \\
\hline & \multicolumn{7}{|c|}{ Index children } \\
\hline $\begin{array}{l}\text { Rhinovirus } \\
\text { Echovirus } \\
\text { Respiratory syncytial virus } \\
\text { Coxsackievirus } \\
\text { Adenovirus }\end{array}$ & $\begin{array}{r}11 \\
1 \\
0 \\
2 \\
2\end{array}$ & $\begin{array}{r}18 \\
7 \\
1 \\
1 \\
1\end{array}$ & $\begin{array}{l}9 \\
3 \\
0 \\
1 \\
1\end{array}$ & $\begin{array}{l}2 \\
0 \\
1 \\
0 \\
0\end{array}$ & $\begin{array}{l}2 \\
0 \\
0 \\
0 \\
0\end{array}$ & $\begin{array}{r}17 \\
1 \\
4 \\
2 \\
5\end{array}$ & $\begin{array}{l}1 \\
0 \\
1 \\
0 \\
1\end{array}$ \\
\hline Adenovirus & \multicolumn{7}{|c|}{ Control children } \\
\hline $\begin{array}{l}\text { Rhinovirus } \\
\text { Echovirus } \\
\text { Respiratory syncytial virus } \\
\text { Coxsackievirus } \\
\text { Adenovirus }\end{array}$ & $\begin{array}{r}11 \\
2 \\
0 \\
2 \\
1\end{array}$ & $\begin{array}{l}3 \\
2 \\
1 \\
1 \\
1\end{array}$ & $\begin{array}{l}3 \\
2 \\
1 \\
0 \\
3\end{array}$ & $\begin{array}{l}1 \\
0 \\
0 \\
0 \\
1\end{array}$ & $\begin{array}{l}3 \\
0 \\
0 \\
0 \\
0\end{array}$ & $\begin{array}{l}3 \\
1 \\
1 \\
0 \\
0\end{array}$ & $\begin{array}{l}0 \\
0 \\
0 \\
0 \\
0\end{array}$ \\
\hline
\end{tabular}


by the control children $(p<0.02)$. Since viruses were isolated in the same proportions from index and control children, the index children had selective infection of the lower respiratory tract by respiratory viruses. Table II shows the clinical diagnosis made in association with illnesses from which viruses were isolated, ${ }^{13} 14$ and clearly shows that all viruses tended to cause wheezing in the index children.

\section{ATOPY}

On the strict diagnostic criteria of Pepys - namely, one or more positive reactions to skin tests to common inhalant allergens-eight index children and seven control children were atopic. When total serum IgE concentrations were compared with the normal range documented by Kjellman et $a^{15} 13$ of the index children and five control children had concentrations more than $2 \mathrm{SD}$ above the geometric mean for age (see figure). All eight index children with positive reactions to skin tests but only three of the seven control children with positive skin test results had raised total serum IgE concentrations.

Positive skin reactions and raised total serum IgE concentrations were both associated with an increased incidence of recurrent wheezing, though this increase did not reach significance. Six $(40 \%)$ of the 15 children with positive skin reactions had four or more episodes of wheezing per year compared with eight $(19 \%)$ of the remaining 45 children with negative reactions $\left(x^{2}=1 \cdot 9, p>0 \cdot 1\right)$. Seven $(39 \%)$ of the 18 children with raised total serum IgE concentrations, and seven $(17 \%)$ of the 42 children with normal serum IgE concentrations wheezed on four or more occasions $\left(x^{2}=2 \cdot 7, p=0 \cdot 1\right)$.

We examined the relation between positive skin reactions, raised total serum IgE concentrations, and the number of infections experienced to determine whether the atopic children in the study were more susceptible to infection. Children with positive skin reactions did not have an increased incidence of respiratory infections compared to those with negative reactions $(6.9+\mathrm{SD} 2.9 v 7.5+3.8 ; \mathrm{t}=0.3$, $\mathrm{p}>0.5)$. Similarly, children with raised total serum IgE concentrations had the same incidence of infections as children with normal serum IgE concentrations $(7 \cdot 4 \div \mathrm{SD} 2.9 v 7 \cdot 3 \pm 3.6 ; \mathrm{t}=0 \cdot 1, \mathrm{p}>0 \cdot 5)$.

\section{Discussion}

We studied a group of 30 children, whose parents' impression that they were having more infections than their siblings was confirmed. The index children were younger and this contributed to their increased susceptibility, but even allowing for age they were significantly more susceptible to infections than their siblings.

Most infections were caused by respiratory viruses. Our bacteriological data, presented elsewhere, ${ }^{16}$ showed that bacteria caused less than $10 \%$ of all infections and bacterial superinfection was not an appreciable problem in these children. We have good evidence that their infections were caused primarily by respiratory viruses. A virus isolation rate of $38 \%$ compares favourably with other ambulatory studies of respiratory illnesses thought to be caused by viruses. ${ }^{217-20}$ Interferon was present in the children's nasopharyngeal secretions during 45 of 103 episodes from which viruses could not be cultured. ${ }^{21}$ We did not attempt to isolate coronaviruses, which have been estimated to cause $15 \%$ of naturally occurring colds, ${ }^{22}$ and we could not avoid freezing specimens, which considerably reduces the yield of myxoviruses such as influenza, parainfluenza, and respiratory syncytial viruses. ${ }^{23}$ Our study design precluded taking paired sera, which would have boosted our rate of positive virus identification. ${ }^{24}$

Our index children not only had increased susceptibility to respiratory virus infections, but they also had an increased incidence of lower respiratory tract infection with wheeze during infections. This tendency to wheeze was only partially explicable in terms of atopy, since not all children with recurrent wheeze were atopic. Wheezing in young children may be partially mechanical owing to the small calibre of the airways. ${ }^{25} \mathrm{We}$ have also shown that defective production of interferon- $\alpha$ may contribute to recurrent wheezing ${ }^{21}$; four of our index children had defective production of interferon- $\alpha$ associated with recurrent infections and wheeze. These children's relative inability to eliminate locally acting viruses such as rhinoviruses from the nasopharynx might lead to spread of the virus to the lower respiratory tract. ${ }^{3}$

The work was generously supported by the Medical Research Council and the Nuffield Foundation. We thank Dr A D B Webster and $\operatorname{Dr} T$ A E Platts-Mills for advice and help and Jean Tuer for performing the IgE assays. The fetal tonsil cells were obtained from Dr S E Reed. Statistical analysis was performed by Mr D G Altman.

Request for reprints to: Dr D A J Tyrrell, Clinical Research Centre, Harrow, Middlesex HA1 3UJ.

\section{References}

${ }^{1}$ Hosking CS, Fitzgerald MG, Shelton MJ. The immunological investigation of children with recurrent infections. Aust Paediatr $\mathcal{F} 1977 ; 13$, suppl:1-108.

${ }^{2}$ Horn MEC, Brain EA, Gregg I, Inglis JM, Yealland SJ, Taylor P. Respiratory viral infection and wheezy bronchitis in childhood. Arch Dis Child 1979;34:23-8.

${ }^{3}$ Horn MEC, Reed SE, Taylor P. Role of viruses and bacteria in acute wheezy bronchitis in childhood: a study of sputum. Arch Dis Child 1979;54:587-92.

4 Horn MEC, Gregg I. Role of viral infection and host factors in acute episodes of asthma and chronic bronchitis. Chest $1972 ; 63$, suppl:44-8.

5 Sims DG, Downham MAPS, Gardner PS, Webb JKG, Weightman D. Study of 8-year-old children with a history of respiratory syncytial virus bronchiolitis in infancy. $\mathrm{Br}$ Med $\mathcal{F} 1978 ; \mathrm{i}: 11-4$.

${ }^{6}$ Minor TE, Baker JW, Dick EC, et al. Greater frequency of viral respiratory infections in asthmatic children as compared with their non-asthmatic siblings. F Pediatr $1974 ; \mathbf{8 5}: 472-7$.

${ }^{7}$ Court SD. The definition of acute respiratory illness in children. Postgrad Med F 1973;49:771-6.

${ }^{8}$ Fox JP, Cooney MK, Hall CE. The Seattle virus watch. V. Epidemiologic observations of rhinovirus infections, 1965-1969, in families with young children. Am 7 Epidemiol 1975;101:122-43.

${ }^{9}$ Grist NR, Ross CA, Bell EJ. Diagnostic methods in clinical virology. 2nd ed. Oxford: Blackwell Scientific Publications, 1974.

10 Gleich GJ, Averbeck AK, Swedlund HA. Measurement of IgE in normal and allergic serum by radioimmunoassay. F Lab Clin Med 1971;77: 690-8.

11 Foucard T. A follow-up study of children with asthmatoid bronchitis. I. Skin test reactions and IgE antibodies to common antigens. Acta Paediatr Scand 1973;62:633-44.

12 Pepys J. Atopy. In: Gell PGH, Coombs RRA, Lachman PJ, eds. Clinical aspect s of immunology. 3rd ed. Oxford: Blackwell Scientific Publications, $1975 ; 877-902$

13 Tyrrell DAJ. Discovering and defining the etiology of acute respiratory viral disease. Am Rev Respir Dis 1963;88:77-84.

14 Medical Research Council Working Party. A collaborative study of the aetiology of acute respiratory infections in Britain 1961-4. Br Med $\mathcal{F}$ $1965 ;$ ii :319-26.

15 Kjellman N-IM, Johansson SGO, Roth A. Serum IgE levels in healthy children quantified by a sandwich technique (PRIST). Clin Allergy $1976 ; 6: 51-9$.

${ }^{16}$ Isaacs D, Clarke JR, Tyrrell DAJ, Webster ADB, Valman HB. The epidemiology of recurrent respiratory infections in pre-school children. In : Modern Problems in Paediatrics. Vol 21. Paediatric respiratory physiology and clinical aspects of paediatric pneumonology. Basel: Karger, 1982 (in press).

${ }^{17}$ Banatvala JE, Anderson TB, Reiss BB. Viruses in acute respiratory infection in a general community. F Hyg (Camb) 1965;63:155-67.

18 Horn MEC, Yealland SJ. Significance of respiratory virus isolation: study in primary schoolchildren. Arch Dis Child 1974;49:516-9.

${ }^{19}$ Horn MEC, Brain E, Gregg I, Yealland SJ, Inglis JM. Respiratory viral infection in childhood. A survey in general practice, Roehampton 1967-1972. f Hyg (Camb) 1975;74:157-68.

${ }^{20}$ Hurrell GD, Sturdy PM, Frood JDL, Gardner PS. Viruses in families. Lancet $1971 ; \mathrm{i}: 769-74$.

${ }^{21}$ Isaacs D, Clark JR, Tyrrell DAJ, Webster ADB, Yalman HB. Deficiency of production of leucocyte interferon (interferon- $\alpha$ ) in vitro and in vivo in children with recurrent respiratory tract infections. Lancet 1981 ;ii 950-2.

${ }^{22}$ McIntosh K, Kapikian RZ, Turner HC, Hartley JW, Parrott RH, Chanock RM. Seroepidemiologic studies of coronavirus infection in adults and children. Am f Epidemiol 1970;91:585-92.

3 Ray CG, Beckwith JB, Hebestreut NM, et al. Studies of the sudden infant death syndrome in King County, Washington. I. The role of viruses. $7 A M A 1970 ; 211: 619-23$

24 Jacobs JW, Peacock DB, Corner BD, Caul EO, Clarke SKR. Respiratory syncytial and other viruses associated with respiratory disease in infants. Lancet 1971 ; i:871-6.

25 Hogg JC, Williams J, Richardson JB, Macklem PT, Thurlbeck WM. Age as a factor in the distribution of lower airway conductance and in the pathologic anatomy of obstructive lung disease. N Engl F Med 1970; 282:1283-7.

(Accepted 5 April 1982) 